\title{
Herbage intake by Churra ewes grazing at two different sward heights
}

\section{Carmen Valdés', A.R. Mantecón ${ }^{2}$, F.J. Giráldez ${ }^{2}$ and F.F. Bermúdez ${ }^{2}$}

\author{
'Departamento de Producción Animal I. Universidad de León. \\ León, Spain \\ ¿Estación Agricola Experimental (CSIC), \\ Apdo. 788, León, Spain
}

(Received 24 February 1995; accepted 8 March 1995)

\begin{abstract}
Herbagc intake and some characteristics of diet selected by grazing Churra ewes were studied on two plots of a Lolium-Festuca-Trifolium pasture maintained at two different sward heights (sward heights (SII): $4 \mathrm{~cm}$ (SSH) and $8 \mathrm{~cm}$ (HSH) in two periods (PE): summer and autumn. Herbage intake was estimated from measurements of faecal output and of digestibility of extrusa samples. With the exception of crude protein content, no significant $(P \geqslant 0.05)$ effects of PE nor SH were detected in the chemical composition and digestibility of herbage on offer. Daily herbage intake ( $\mathrm{g} \mathrm{OM} / \mathrm{kg}$ live weight) was greater $(P \leqslant 0.10)$ on IISH than on SSH and was also greater $(P \leqslant 0.05)$ in autumn than in summer. Significant effects of $\mathrm{PE}(P \leqslant 0.01)$ and $\mathrm{SH}(\mathrm{P} \leqslant 0.05)$ were obtained in the selection ratios (calculated as the content of each considerate component in extrusa samples divided by its content in the herbage on offer) for all chemical fractions and for digcstibility. Except for cellulose, interaction between main factors had a significant $(P \leqslant 0.001)$ effect on the selection ratios.
\end{abstract}

KEY WORDS: sheep, pastures, grazing, intakc

\section{INTRODUCTION}

Grazing behaviour of ruminants is complex. Forage intake and selectivity grazing are functions of numerous pasture and animal characteristics (Arnold, 1964; Cordova et al., 1978; Milne, 1991). Intake has been correlated with forage availability, sward height and nutritional quality (Hodgson, 1968; Allison, 1985; Minson, 1987). Such complexity has made prediction of forage intake and 
animal performance of grazing ruminants very difficult. However, a knowledge of the intake of nutrients obtained by the animal from pasture is essential to establish whether nutritional requirements can be met and to assess the likely animal performance and levels of output.

Sheep production based on grazing systems could be an alternative to agricultural production on irrigated areas in Spain, in which agricultural has led to surplus production. The study of factors influencing grazing intake by the most important sheep breeds should be carried out to obtain the basic information necessary for developing grazing systems in Spanish irrigated areas. The Churra breed is the more important nucleus of milk-producing sheep in Spain. Nevertheless, at present, there are few data on intake of herbage by Churra sheep as affected by herbage availability. The aim of the current work was to study the effect of height of sward on herbage intake by grazing Churra ewes taking into account diet selection on an irrigated pasture.

\section{MATERIAL AND METHODS}

\section{Pasture and treatments}

The experiment was conducted on the Estación Agricola Experimental (CSIC) in León (NW Spain) during 1989. The measurements were carried out on two paddocks, each of 0.1 ha, of a sward that had been sown with a mixture of Lolium perenne, Festuca arundinacea and Trifolium repens in 1985. The experimental paddocks had been grazed since 1986 from April to November.

The work was carried out according to two periods (PE) $\mathrm{x}$ two sward heights (SH) experimental design. The target sward heights were: $4 \mathrm{~cm}$ (short sward height $-\mathrm{SSH}$ ) and $8 \mathrm{~cm}$ (high sward height $-\mathrm{HSH}$ ) on each experimental plot.

\section{Animals and management}

Churra ewes among 3 and 5 years old were used in this work. Two balanced groups, of five animals each, were identified and designated "experiment sheep". Each experimental group was allocated to one of the two SH treatment plots. These animals remained grazing on their plot until the end of the experiment.

Throughout the experimental period, the requisite sward height was maintained by increasing or decreasing the number of animals on any plot whilst retaining the basic nucleus of experiment sheep within each plot. 


\section{Animal measurements}

Animals were weighed a week before starting each herbage intake measurement period and the day after its end.

Herbage intake was estimated over 5-day periods in summer (3-7 July) and autumn (18-22 September) from measurements of faecal output and of digestibility of organic matter of herbage selected by grazing sheep. Faecal output of experimental sheep was determined by total collection using harnesses. Faecal bags were changed once daily at $9.30 \mathrm{~h}$. The digestibility of herbage selected was estimated from samples collected on the first four days of each faeces collection period using six oesophageal fistulated sheep. One sample per day was obtained from each animal, with three animals sampled in the morning (9.30) and three in the evening (18.30), and alternating the time of collection in each paddock. Extrusa samples obtained from the same animal on each period were bulked for analytical determinations.

\section{Sward measurements}

Sward surface height was measured twice weekly using the Hill Farming Research Organisation sward stick (Barthram, 1986). Herbage height was recorded at 50 random locations per plot on each occasion. The herbage mass on offer was estimated twice during each herbage intake measurement period, by cutting four quadrates $(30 \times 30 \mathrm{~cm})$ per paddock to ground level. Mean herbage mass in each treatment was calculated as the average of the two measurements, by scaling up to one ha.

\section{Analytical determinations}

Faeces, herbage and extrusa samples were dried in a forced air oven at $60^{\circ} \mathrm{C}$ to a constant weight. After drying, all samples were ground to pass a 1-mm screen. Ash content was determined using A.O.A.C. (1980) method. All data were expressed on an ash free (organic matter - OM) basis.

In vitro organic matter digestibility (IVD) was determined in herbage and extrusa samples by the technique of Tilley and Terry (1963). Herbage and extrusa samples were also analysed for nitrogen, neutral detergent fibre (NDF), cellulose (CEL) and permanganate lignin (LIG) contents. Nitrogen was determined by the Kjeldahl procedure (A.O.A.C., 1980). Samples were analysed for NDF, CEL and LIG according to Goering and Van Soest (1970). 


\section{Estimation of selection of diet}

Selection exerted by the grazing animals was estimated using selection ratios, calculated according to Hodgson (1979) as the content of each considerate component in the diet (extrusa samples) divided by its content in the herbage on offer. Selection ratios were calculated for IVD, CP, NDF, CEL and LIG.

\section{Statistical analysis}

Data were subjected to variance analysis using Statgraphics (Statistical Graphics Corporation, 1986) with PE and SH in the statistical model. PE x SH interaction was also included in the model for herbage intake, diet characteristics and selection rate data.

\section{RESULTS}

Mean sward heights $(\mathrm{cm})$ and herbage masses $(\mathrm{kg} \mathrm{OM} / \mathrm{ha})$ are shown in Table 1 . Small differences between actual and target sward heights were obtained in both periods, being the mean obtained in summer greater $(P \leqslant 0.001)$ than the obtained in autumn. Herbage mass paralleled sward height values, although was not affected by PE.

Within each period (Table 1) difference $(P \leqslant 0.05)$ in all the chemical fractions and IVD of herbage has been observed between both plots. On the other hand, in

TABLE 1

Sward height $(\mathrm{cm})$, herbage mass ( $\mathrm{kg} \mathrm{OM} /$ ha and chemical composition $(\mathrm{g} / \mathrm{kg} \mathrm{OM}$ ) in vitro organic matter digestibility (\%) of herbage on offer as affected by period (PE) and sward height (SH)

\begin{tabular}{lccccccc}
\hline & \multicolumn{2}{c}{ Summer } & \multicolumn{2}{c}{ Autumn } & & & \\
\cline { 2 - 8 } & SSH & HSH & SSH & HSH & SEM & PE & SH \\
\hline Sward Height & $3.8^{\mathrm{a}}$ & $8.8^{\mathrm{b}}$ & $3.4^{\mathrm{a}}$ & $7.4^{\mathrm{b}}$ & 0.16 & $*$ & $* * *$ \\
Herbage mass & $600^{\mathrm{a}}$ & $1247^{\mathrm{c}}$ & $657^{\mathrm{a}}$ & $1113^{\mathrm{b}}$ & 49.1 & NS & $* *$ \\
Chemical composition & & & & & & & \\
Crude protein & $174^{\mathrm{ab}}$ & $162^{\mathrm{a}}$ & $254^{\mathrm{c}}$ & $187^{\mathrm{b}}$ & 6.8 & $*$ & $*$ \\
Neutral detergent fibre & $699^{\mathrm{c}}$ & $585^{\mathrm{b}}$ & $500^{\mathrm{a}}$ & $602^{\mathrm{b}}$ & 24.6 & $\mathrm{NS}$ & $\mathrm{NS}$ \\
Cellulose & $280^{\mathrm{c}}$ & $259^{\mathrm{b}}$ & $208^{\mathrm{a}}$ & $259^{\mathrm{b}}$ & 8.5 & NS & NS \\
Lignin & $68^{\mathrm{c}}$ & $45^{\mathrm{b}}$ & $33^{\mathrm{a}}$ & $45^{\mathrm{b}}$ & 4.1 & NS & NS \\
In vitro organic & $65.6^{\mathrm{a}}$ & $76.7^{\mathrm{c}}$ & $76.8^{\mathrm{b}}$ & $70.6^{\mathrm{b}}$ & 2.01 & NS & NS \\
matter digestibility & & & & & & & \\
\hline
\end{tabular}

SSH, HSH: Short sward height, high sward height. SEM: Pooled standard error of the mean. Values in the same row with different superscripts are significantly different $(P \leqslant 0.05)$ 
TABLE 2

Organic matter intake ( $\mathrm{g} / \mathrm{kg} \mathrm{W} /$ day) and chemical composition $(\mathrm{g} / \mathrm{kg} \mathrm{OM})$ and in vitro organic matter digestibility (\%) of the diet selected by sheep (extrusa) as affected by period (PE) and sward height (SH)

\begin{tabular}{lrrrrrrrr}
\hline & \multicolumn{9}{c}{ Summer } & \multicolumn{2}{c}{ Autumn } \\
\cline { 2 - 9 } & SSH & HSH & SSH & HSH & SEM & PE & SH & PExSH \\
\hline Organic matter intake & $13^{\mathrm{a}}$ & $22^{\mathrm{b}}$ & $21^{\mathrm{b}}$ & $31^{\mathrm{c}}$ & 1.69 & $*$ & NS & NS \\
Crude protein & $203^{\mathrm{a}}$ & $201^{\mathrm{a}}$ & $297^{\mathrm{b}}$ & $283^{\mathrm{b}}$ & 2.55 & $* * *$ & NS & NS \\
Neutral detcrgent fibre & $612^{\mathrm{c}}$ & $528^{\mathrm{ab}}$ & $506^{\mathrm{a}}$ & $539^{\mathrm{b}}$ & 3.78 & $* *$ & $* * *$ & $* * *$ \\
Cellulose & $263^{\mathrm{d}}$ & $230^{\mathrm{c}}$ & $183^{\mathrm{a}}$ & $207^{\mathrm{b}}$ & 1.92 & $* * *$ & $*$ & $* * *$ \\
Lignin & $54^{\mathrm{b}}$ & $59^{\mathrm{b}}$ & $36^{\mathrm{a}}$ & $33^{\mathrm{a}}$ & 1.73 & $* * *$ & NS & NS \\
In vitro organic & & & & & & & & \\
matter digestibility & $70^{\mathrm{a}}$ & $77^{\mathrm{c}}$ & $80^{\mathrm{c}}$ & $84^{\mathrm{d}}$ & 0.33 & $* * *$ & $* * *$ & NS \\
\hline
\end{tabular}

SSH, HSH: short sward height, high sward height. SEM: pooled standard error of the mean in the same row, values with different superscripts are significantly different $(P \leqslant 0.05)$

TABLE 3

Sclection ratios for crudc protein, neutral detergent fibre, cellulose, lignin and in vitro organic matter digestibility as affected by period $(\mathrm{PE})$ and sward height $(\mathrm{SH})$

\begin{tabular}{lccccccccc}
\hline & \multicolumn{2}{c}{ Summer } & \multicolumn{2}{c}{ Autumn } & & & & \\
\cline { 2 - 9 } & SSH & HSH & SSH & HSH & SEM & PE & SH & PExSH \\
\hline Crude protein & $1.21^{\mathrm{a}}$ & $1.24^{\mathrm{a}}$ & $1.17^{\mathrm{a}}$ & $1.52^{\mathrm{b}}$ & 0.015 & $* * *$ & $* * *$ & $* * *$ \\
Neutral detergent fibre & $0.88^{\mathrm{a}}$ & $0.90^{\mathrm{a}}$ & $1.01^{\mathrm{b}}$ & $0.89^{\mathrm{a}}$ & 0.006 & $* *$ & $*$ & $* * *$ \\
Cellulose & $0.94^{\mathrm{c}}$ & $0.87^{\mathrm{b}}$ & $0.88^{\mathrm{b}}$ & $0.80^{\mathrm{a}}$ & 0.005 & $* * *$ & $* * *$ & NS \\
Lignin & $0.79^{\text {ab }}$ & $1.32^{\mathrm{c}}$ & $1.08^{\mathrm{b}}$ & $0.74^{\mathrm{a}}$ & 0.038 & $* *$ & $*$ & $* * *$ \\
In vitro organic & & & & & & & & \\
matter digestibility & $1.07^{\mathrm{b}}$ & $1.00^{\mathrm{a}}$ & $1.04^{\mathrm{b}}$ & $1.19^{\mathrm{c}}$ & 0.046 & $* * *$ & $*$ & $* * *$ \\
\hline
\end{tabular}

SSH, HSH: short sward height, high sward height. SEM: pooled standard error of the mean in the same row, values with different superscripts are significantly different $(P \leqslant 0.05)$

the SSH herbage both all the chemical contents and IVD changed between summer and autumn, whereas in the herbage of the HSH plot no differences were detected in NDF, CEL and LIG contents. Only CP content of herbage was significantly affected $(\mathrm{P} \leqslant 0.05)$ by the main factors $(\mathrm{PE}$ and $\mathrm{SH})$.

Daily herbage intakes relative to live weight $(\mathrm{g} \mathrm{OM} / \mathrm{kg} \mathrm{LW} /$ day) are presented in Table 2. Herbage OM intake was greater $(P \leqslant 0.05)$ in autumn than in summer and tended $(\mathrm{P} \leqslant 0.10)$ to be less in SHS than in HSH. The chemical composition $(\mathrm{g} / \mathrm{kg} \mathrm{OM})$ of sheep diets (extrusa samples) is also displayed in Table 2. Both SH and PE as well as main factors interaction - with the exception of CEL - had a significant $(P \leqslant 0.001)$ effect on selection ratios (Table 3$)$. 


\section{DISCUSSION}

Although only crude protein content of herbage on offer was affected by the sward height, other differences on chemical composition between SSH and HSH were also found within periods. In summer, differences in chemical composition and IVD herbage suggest that the nutritive quality of herbage was worse in SSH than in HSH, whereas in autumn herbage was poorer in HSH than in SSH. In SSH differences between summer and autumn could reflect better nutritive quality of herbage in autumn and could point out expected differences between mature herbage (summer) and leafy regrowth (autumn). However, the differences observed within HSH did not seem to be related to this type of change. The maintenance of sward heights during a period of declining herbage growth led to a reduction of grazing pressure in autumn. In according with Gibb and Baker (1989), relaxation of grazing pressure allowed the accumulation of more dead material on taller swards than on the shorter ones. Then, in HSH, the differences between summer and autumn in chemical composition and digestibility could reflect this fact.

The nutritive value of the diet varied with season. IVD and CP content were markedly greater in autumn than in summer. In the same way, both cell wall NDF and its fractions contents were less in autumn than in summer. Differences between seasons in these parameters were not so clear in the herbage on offer as in the diets. Then, as it could be expected (Jung et al., 1989; Newman et al., 1992), the nutritive value of the diet does not exactly parallel the nutritive value of the herbage on offer, because size of the differences between herbage and diet composition changed with period. In our work, the nutritive quality of diet selected seemed to be better than that of herbage on offer, but a greater increase was noted in autumn than in summer. This could suggest that, in this study, selection intensity was not as great in summer as it was in autumn. Likewise, selection ratios were nearer to 1 in summer than in autumn (see Table 3). Similar effects of season on selection ratios for IVD, CP, NDF and LIG have been obtained by Jung et al. (1989), who pointed to the degree of selectivity increasing during the grazing season.

Although SH had a significant effect in all the selectivity index, there were remarkable differences between summer and autumn. Whereas in autumn the selection ratios suggest a greater selection for a more nutritive diet in $\mathrm{HSH}$ than in $\mathrm{SSH}$, the selection ratios obtained in the $\mathrm{HSH}$ in summer could point to a selection against NDF and CEL, a selection for CP and LIG, and no selection for IVD (see Table 3).

Generally, it has been observed that animals selected diets that are more digestible than the herbage as a whole (Fontenot and Blaser, 1965; Jung and Koong, 1985), however, our results agree with those obtained by Jung et al. 
(1989), who also observed selectivity index greater than 1 for lignin and no selection for IVD in some of their experimental periods.

As expected, herbage organic matter intake was greater in HSH than in SSH. Several studies have shown that herbage intake by sheep grazing in temperate pastures is severely depressed when sward height falls under $4 \mathrm{~cm}$ (Allden and Whittaker, 1970; Penning, 1986; Orr et al., 1990). One of the main arguments that could be used to explain reduced intake where there is a low sward height is that the amount that can be taken with each bite is low (Stobbs, 1973; Penning, 1986; Orr et al., 1990). In a mechanistic explanation of reduced intake on short swards, the lower weight of each bite can partly be offset by the animal increasing the number of harvesting bites. However, there is an upper limit to the total number of bites that animals will take each day, and as a result, increasing the number of harvesting bites will not compensate for the reduced of each bite (Minson, 1987). On the other hand, as it was pointed out, selection ratios (see Table 3) seem to reflect a some degree of herbage selection. Such selection would lead to reduce the size of prehended bites and, as a consequence, herbage intake would be limited (Illius, 1986). Than, the very low herbage intake in SSH in summer could be explained by a situation of that kind.

Herbage organic matter intake was also affected by period (see Table 2), the mean values being greater in autumn than in summer. Differences between seasons in the quantity of herbage intake by grazing animals were also noted by several authors (Baker et al., 1980; Jung and Sahlu, 1989; Penning et al., 1991). Herbage intake increased as digestibility of herbage intake increased and this agrees with the results obtained by several workers (Hodgson, 1968; Hodgson et al, 1991). However, it should be noted that perhaps some changes in sward canopy structure between summer and autumn resulted in a more heterogeneous structure in autumn. Than, a greater selection in autumn could be a consequence of a selection for patches more easy harvested: a horizontal selection (Milne, 1991). In this case, selection could not be a limit to the size of bites as it could be in summer.

\section{CONCLUSION}

Although height of herbage affects both quantity and quality of herbage intake by Churra sheep, the complexity of factors affecting selective grazing made difficult to predict herbage intake from height and chemical composition of the herbage on offer. 


\section{REFERENCES}

A.O.A.C., 1980. Official Methods of Analysis of the Association of Official Agricultural Chemist. 13 th Edition. Washington

Allden W.G., Whittaker I.A. McD., 1970. The determinants of herbage intake by grazing sheep: The interrelationship of factors influencing intake and availability. Aust. J. Agric. Res. 21, 755-766

Allison C.D., 1985. Factors affecting forage intake by range ruminants: A review. J. Range Manage. $38,755-781$

Arnold G.W., 1964. Factors within plants associations affecting the behaviour and performance of grazing animals. In: D.J. Crips (Editor). Grazing in Terrestrial and Marine Environments. Brackwell Scientific Publ., Oxford. pp. 135-154

Baker R.D., Alvarez F., Le Du Y.L.P., 1980. The effect of herbage allowance upon herbage intake and performance of suckler cows and calves. Grass Forage Sci. 36, 201-210

Barthram G.T., 1986. Experimental techniques: the HFRO sward stick. In: The Hill Farming Research Organisation. Bienna! Report 1984-85. Haddintong: D. and J. Croal Ltd. pp. 29-30

Cordova F.J., Wallace J.D., Pieper R.D., 1978. Forage intake by grazing livestock: A review. J. Range Manage. 31, 430-443

Fontenot J.P., Blaser R.E., 1965. Symposium of factors influencing the voluntary intake of herbage by ruminants: Selection and intake by grazing animals. J. Anim. Sci. 24, 1202-1208

Gibb M.J., Baker R.D., 1989. Effect of changing grazing severity on the composition of perennial ryegrass/white clover swards stocked continuously with beef cattle. Grass Forage Sci. 44, 329-334

Goering H.D., Van Soest P.J., 1970. Forage fiber analyses (apparatus, reagents, procedures and some applications). Agricultural Handbook, United States Department of Agriculture, No. 379

Hodgson J., 1968. The relationship between the digestibility of a sward and the herbage consumption of grazing calves. J. Agric. Sci., Camb. 70, 47-51

Hodgson J., 1979. Nomenclature and definitions in grazing studies. Grass Forage Sci. 34, 11-18

Hodgson J., Forbes T.D.A., Armstrong R.H., Beattie M.M., Hunter E.A., 1991. Comparative studies of the ingestive behaviour and herbagc intake of shecp and cattle grazing indigenous hill plant communities. J. Appl. Ecology 28, 205-227

Illius A.W., 1986. Foraging behaviour and diet selection. In: O. Gudmunson (Editor). Grazing Research at Northern Latitudes. New York: Plenum Press Series A: Life Sciences, pp. 227-236

Jung H.G., Sahlu T., 1989. Influence of grazing pressure on forage quality and intake by sheep grazing smooth bromegrass. I. Anim. Sci. 67, 2089-2097

Jung H.G., Koong L.J., 1985. Effects of hunger satiation on diet quality by grazing sheep. J. Range Manage. 38, 271-278

Jung H.G., Bennet G.L., Sahlu T., 1989. Magnitude of dict sclection by sheep grazing smooth bromegrass. J. Anim. Sci. 67, 2106-2115

Milne J.A., 1991. Diet selection by grazing animals. Proc. Nutr. Soc. 50, 77-85

Minson D.J., 1987. Plant factors affecting intake. In: R.W. Snaydon (Editor). Managed Grasslands. Elsevier, Amsterdam pp. 137-144

Newman J.A., Parsons A.J., Harvey A., 1992. Not all sheep prefer clover: diet selection revisited. J. Agric. Sci., Camb. 119, 275-283

Orr R.J., Parsons A.J., Penning P.D., Treacher T.T., 1990. Sward composition, animal performance and the potential production of grass/white clover swards continuously stocked with sheep. Grass Forage Sci, 45, 325-336

Penning P.D., 1986. Some effects of sward conditions on grazing behaviour and intake by sheep. In: O. Gudmundsum (Editor). Grazing Research at Northern Latitudes. New York: Plenum Press Series A: Life Sciences, pp. 219-226 
Penning P.D., Parsons A.J., Orr R.J., Treacher T.T., 1991. Intake and behaviour responses by sheep to changes in sward characteristics under continuously stocking. Grass Forage Sci. 46, 15-28

Statistical Graphics Corporation, 1986. Statistical Graphics User's Guide. Rockville, Maryland, U.S.A.

Stobbs T.H., 1973. The effect of plant structure on the intake of tropical pastures. I. Variation in the bite size of grazing cattle. Aust. J. Agric. Res. 34, 809-819

Tilley J.M.A., Terry R.A., 1963. A two-stage technique for the in vitro digestion forage crops. J. Brit. Grassl. Soc. 18, 104-111

\section{STRESZCZENIE}

\section{Pobranic ziclonki przez owce Churra $x$ pastwisk o dwóch różnych wysokościach porostu}

Pobranie zielonki i charakterystyke wybranej przez owce Churra paszy badano na dwóch kwaterach pastwiska (Lolitum-Festuca-Trifolium), przy dwóch różnych wysokościach porostu: niski (SSH) $-4 \mathrm{~cm}$ i wysoki (HSH) $-8 \mathrm{~cm}$, oraz w dwóch sezonach (PE): letnim i jesiennym. Pobranie zielonki oznaczono na podstawie ilości wydalonego kału i strawności prób pobranych z przetokowanego przełyku owiec. Skład chemiczny i strawność pobieranych pasz nie różnily się istotnie $(P \geqslant 0.05)$ w zależności od sezonu i wysokości porostu, z wyjątkiem zawartości białka ogólnego. Dzienne pobranie ( $\mathrm{g}$ substancji organicznej na $1 \mathrm{~kg}$ masy ciała, w grupie HSH bylo nieco większe niż w grupie SSH $(P \leqslant 0.10)$, a istotnie większe $(P \leqslant 0.05)$ jesienią niż latem. Stwierdzono istotny wplyw sezonu $(\mathrm{P} \leqslant 0.01)$ i wysokości porostu $(\mathrm{P} \leqslant 0.05)$ w pobrancj przez owce ziclonce (obliczony jako zawartość każdej $\mathrm{z}$ roślin w próbach pobranych $\mathrm{z}$ przełyku. podziclona przez ich zawartość w oferowanym porościc) na skład chemiczny składników pokarmowych i ich strawność. Interakcja wysokości porostu $x$ sezon była wysoce istotna dla wszystkich składników pokarmowych, 7 wyjątkiem celulozy. 